\title{
Birth weight, milk production and mortality rate in crossbred cattle (Dwarf taurine $\times$ Zebu) in Togo
}

\author{
S. Boma ${ }^{1 *}$, G-K. Dayo ${ }^{2}$, Y. Lombo ${ }^{3}$, A. Kossoga ${ }^{3}$, Y.A. Djagba ${ }^{3}$, E. \\ Mollong $^{4}$, T. N'Féidé ${ }^{3}$, K. Seme ${ }^{5}$, K.S. Omasaki ${ }^{6}$
}

\begin{abstract}
${ }^{1}$ Institut Togolais de Recherche Agronomique (ITRA-Togo), Centre International de Recherche-Développement sur l'Elevage en zone Subhumide (CIRDES Bobo-Dioulasso), 01 B.P. 454 Bobo-Dioulasso; ${ }^{2}$ Centre International de Recherche-Développement sur l'Elevage en zone Subhumide (CIRDES Bobo-Dioulasso, Burkina Faso), 01 B.P. 454 Bobo-Dioulasso 01 - Burkina Faso ; ${ }^{3}$ Institut Togolais de Recherche Agronomique (ITRA-Togo), BP: 1163 Lomé-Cacavéli ; ${ }^{4}$ Université de Lomé, Faculté des Sciences, Sciences et Technologies, BP: 1515 Lomé ; ${ }^{5}$ Université de Lomé, Ecole Supérieure d'Agronomie, BP: 1515 Lomé ; ${ }^{6}$ Animal Breeding and Genomics Group, Department of Animal Sciences, Kisii University, Kisii, Kenya, Phone: +254 702506302 *Corresponding author: Tel: 00226 52978731, E-mail: bomasoudah@gmail.com
\end{abstract}

Journal of Livestock Science (ISSN online 2277-6214) 12: 111-119

Received on 05/12/20; Accepted on 15/2/2021; published on 26/2/2021

doi. 10.33259/JLivestSci.2021.111-119

\begin{abstract}
Somba cattle is one of the two trypanotolerant West-African Dwarf (WAD) breeds. Crosses between taurine (Bos taurus) and Zebu (Bos indicus) breeds are reported in various localities in West-Africa. The aim of this study was to assess the birth weight, the milk production and the mortality rate in crossbred cattle (Dwarf taurine $\times$ Zebu) in Togo. The study was carried out between 2015 and 2017 in February (dry season), May and September (rainy season) of each year in two Prefectures (Mô and Tchaoudjo) located in Central Administrative region of Togo. A total of 207 calves and 290 milking cows were randomly sampled for the study. Calves consisted of $72 \mathrm{WAD}, 67 \mathrm{Zebu}$ and 68 crossbred (WAD $\times$ Zebu) phenotypically taurine. The male calves weigh $17.70 \pm 2,6 \mathrm{~kg}$ against $16.59 \pm 1.97 \mathrm{~kg}$ for the female in crossbreeds; $13.76 \pm 1.07 \mathrm{~kg}$ and $12.37 \pm 1.16 \mathrm{~kg}$ in $\mathrm{WAD}$ and $22.55 \pm 3.34 \mathrm{~kg}$ and $19.66 \pm 2.15 \mathrm{~kg}$ in Zebus cattle. The milk production was significantly higher in the crossbreed $(0.68 \pm 0.27 \mathrm{~L})$ than in WAD $(0.46 \pm 0.15 \mathrm{~L})$ on the one hand and it was influenced by the rank of calving $(P=0.000)$ on the other hand. The mortality rates were $10.98 \pm 3.41 \% ; 11.85 \pm 4.19 \%$ and $12.17 \pm$ $5.06 \%$ in Crossbred, WAD and zebus respectively and no significant difference was observed among the three phenotypes. However, the calving-season had significant effect $(P=0.003)$ on the mortality rates. In the light of the foregoing figures, we come to conclusion that Somba breed performs far less compared to the crossbreed (Dwarf taurine $\times$ Zebu) and Zebus phenotypes in terms of birth weight and milk production.
\end{abstract}

Keywords: Dwarf taurine; crossbreed; birth weight; milk production; mortality; Togo. 


\section{Introduction}

Beef and milk production in the Gulf of Guinea is based on the selection of different life-history traits of two subspecies of cattle, namely: Bos taurus (humpless cattle or taurine) and Bos indicus (humped cattle or Zebu) (Okeyo et al., 2015). Taurine cattle differ fundamentally from Zebu with their easy adaptation to the humid and sub-humid environments which are infested with tsetse flies on the one hand and their trypanotolerance behavior (Santoze and Gicheha, 2019) on the other hand. Morever, Zebu cattle on their part are considered trypanosusceptible but are better adapted to sub-sahelian environment. Each group of West-African cattle is unique based on the agro-ecological zones they inhabit. Since the major droughts of 1970's, Zebu cattle have been increasing in number in the North. Very recently they have spread into the southern part, especially in the West African coastal region where there is abundant grazing and naturally, a natural raising ground of humpless cattle (Okeyo et al., 2015; Courtin et al., 2009; Hanotte et al., 2003).

In Benin and Togo, Somba and Lagune cattle are the main local Dwarf taurine breeds (Belemsaga et al., 2005). Laguna breed is located in the South, littoral areas while Somba breed is found in the northern, dry savannah area (Atacora mountain region) and wet savannah (middle center of the rural area) (Santoze and Gicheha, 2019; Boma et al., 2018; Koudandé et al., 2009; Adanléhoussi et al., 2003). In addition, Borgou cattle breed (a genetically stabilized crossbreed between Somba and Zebu) and the Fulani Zebu breed (Bos indicus) are also found in the Somba breeding zones. In wet savannah, two phenotypic crossbreeds can be distinguished: Dwarf taurine (phenotypically pure Somba breed) and humpless crossbreeds (Dwarf taurine $\times$ Zebus). Dwarf taurine phenotype cattle are recognized by their small size, height at the withers of about $96 \mathrm{~cm}$, while the crossbreed animals with humpless phenotype are large in size with height at the withers size of $99.3 \pm 3.9 \mathrm{~cm}$ (Boma et al., 2018; Adanlehoussi et al., 2003). According to information collected from farmers, humpless crossbreed phenotypes have better survival fitness among the offspring from crossbreeding between local taurine cows and Zebu bulls. These crossbreeds are characterized by their humpless, small horns, docility and rusticity and are therefore used, like the Somba cattle, for traditional rites, engagement/weeding and various celebrations (Santoze and Gicheha, 2019; Dossa and Vanvanhossou, 2015).

Previous surveys have evidenced that the need for livestock products is ceaselessly increasing. Nonetheless, both the indigenous and commercial livestock industry is however facing several challenges arising from climate change today. These challenges include the harsh environment conditions (heat and drought), poor pasture, scarce water and parasitic infectious diseases (ticks and tick-borne diseases and animal trypanosomiasis) among others (Santoze and Gicheha, 2019). Although, indigenous livestock are adapted to the local environments, the quality of milk and meat they produce is low compared to the commercial breeds. Most indigenous African cattle breeds have not been selected consistently for productivity gains, but the main selective focus has been on survival, in often unpredictable, harsh and changing environmental conditions. WestAfrican taurine cattle are known to be genetically well adapted to such epidemiological and environmental conditions. Crossbreeds (Dwarf taurine $\times$ Zebu) are thus very attractive genetic material for farmers, as they are considered to have earlier parturition and better dairy production than the local Bos taurus (Youssao et al., 2000). Therefore, developing breeding programs on the targeted crossbred population to improve specific productivity traits in response to the demands of the farmer's and to the local ecological conditions may be crucial (Tano et al., 2003).

The present study aims to evaluate the unique characteristics of taurine crossbred cattle while unfolding the opportunities and the requisite to exploit these resources in response so as to answer the needs of the farmers. The study focuses mainly on the birth weight, milk production and mortality rate in Somba crossbred cattle under traditional breeding conditions in the Guinea Savannah of Togo.

\section{Materials and methods}

The survey was conducted between 2015 and 2017 in February, May and September of each year in two prefectures (Prefecture of Mô and Prefecture of Tchaoudjo) in the Central Administrative region of Togo (Figure 1). The two prefectures are $120 \mathrm{~km}$ apart. In the area under this study, June to October are the wettest months with a rainfall range from 1,074 to $1,649 \mathrm{~mm}$ per annum. The dry season, from November to April, is punctuated by the Harmattan, a northeast wind characterized by warm days and cold nights. The utilization of natural pasture throughout the year is the main feeding practice for the cattle herds.

The two-phenotypes (Dwarf $\times$ Zebu and Somba) included in the survey are presented in figure 2 . Sampling of the two taurine phenotypes was performed with the help of animal breeders using the information on the animal's genealogy. The evaluation of the calf weight performance and mortality rate was carried out on a sample of 207 individuals randomly selected (Table 1), which were the offspring of Dwarf taurine (72 calves), Zebu (67 calves) and crossbred cattle (Dwarf taurine $\times$ Zebu) $(68$ calves). For milk performance, only crossbred cattle (156 cows) and Dwarf taurine (134 cows) were randomly sampled.

\section{Physical performance data collection}

Physical performance measurements included Birth Weight (BW) and Chest Girth (CG) of the calves of two to three days old after calving. The BW were measured using a scale (Constant hanging scale: 14192 - 64; 
accuracy 200g) while the measurements of CG were performed using a barometric tape. Other non-genetic parameters identified were the calf sex and the calving season.

Mortality

The mortality rate was assessed using calves from zero to one year old in conjunction with the series of BW surveys between 2015 and 2017 from February (dry season) to May and in September (rainy season) of each year. This survey started by counting calves from zero to one year old in the herds where calving was recorded.

\section{Evaluation of milk yield}

Milk production measurements were conducted for three months for each cow in the sampled population. Milking was done by trained herdsmen/animal owners to read the volumes in the test tubes. These measurements were taken individually for each cow, once daily, between 6:00 and 7:30 a.m. starting on the $5^{\text {th }}$ day after calving using a graduated bottle. The calves were used to initiate the flow of the milk. The cows were manually milked until the apparent dry-out. Due to seasonal mobility and inaccessibility to some Zebu herds in the localities surveyed, the milk production assessment was focused exclusively on Dwarf taurine and crossbred phenotype cows.

\section{Data analysis}

The statistical software SPSS 20 was used for the data analyses. The "General Linear Model" (GLM) for the multiple comparisons of parameters (birth weight, milk production and mortality rate) was applied. Tukey's multiple-rang test was performed to test the difference among quantitative values (weight performance and milk production) and the Chi-square statistical to test for the mortality rate distribution for each phenotype.

\section{Results}

\section{Physical performance of the calves}

Single births were noted at $100 \%$ in crossbred cattle (68 births) and Dwarf taurine (72 births). Among the Zebus, $97.01 \%$ of the calves of the sample were single-born against 3\% (2 cases out of 67 ) for the twin births. In global, the Zebu calves were more overweight compared to both Dwarf taurine and crossbred cattle.

The lowest weight performance was obtained in Dwarf taurine breed $(13.01 \pm 1.32)$ and the highest in Zebu $(20.69 \pm 3.43 \mathrm{~kg})$. The average weight of the crossbred cattle $(17.09 \pm 2.34 \mathrm{~kg})$ was between the values obtained for Somba cattle and Zebu. Overall, male calves were heavier $(17.92 \pm 4.39 \mathrm{~kg})$ than females $(15.97 \pm$ $3.47 \mathrm{~kg}$ ) (Table 2). The lowest weight performance $(14.50 \pm 1.22 \mathrm{~kg}$ ) was recorded in Zebu in twin birth (female sex). The average weights for males and females were respectively $17.70 \pm 2.3 \mathrm{~kg}$ and $16.59 \pm 1.97 \mathrm{~kg}$ for crossbreds, $13.76 \pm 1.07 \mathrm{~kg}$ and $12.37 \pm 1.16 \mathrm{~kg}$ for Dwarf taurine, $22.55 \pm 3.34 \mathrm{~kg}$ and $19.66 \pm 2.15 \mathrm{~kg}$ for the Zebus. The CG recorded was $55.92 \pm 1.72 \mathrm{~cm}, 58.91 \pm 1.82 \mathrm{~cm}, 61.07 \pm 3.40$ respectively for Dwarf taurine Somba, crossbred cattle and Zebu. A positive and significant correlation was found between BW and CG traits, Linear $\mathrm{R}^{2}$ equal to 0.592 (Dwarf taurine), 0.494 (humpless crossbred cattle) and 0.640 (Zebus) (Figure 3). High phenotypic variance of BW for calves together with medium CG was observed (Table 3). The multiple comparison test indicated a positive difference from $4.08 \mathrm{~kg}$ (31\%; ES: 0.42$)$ in the BW of crossbred calves compared to Dwarf calves. BW depends significantly of the calf sex and the calving season, whereas CG was similar regardless of the season. Yet, by season, the survey indicates the absence of interactions regardless of villages and the animal phenotype.

\section{Milk production performance of the cows studied}

The average daily milk production over a 90 -day period in the Dwarf taurine cattle population was 0.58 $\pm 0.25 \mathrm{~L}$, with a monthly average of $17.24 \pm 7.63 \mathrm{~L}$. Crossbred cows had a better milk production $(0.68 \pm 0.27 \mathrm{~L})$ than that of Dwarf taurine cows $(0.46 \pm 0.15 \mathrm{~L})$ (Figure 4). The milk production recorded in both types was influenced by-lactation rank $(P=0.000)$ with a maximum average of $0.96 \pm 0.24 \mathrm{~L}$ and a minimum of $0.52 \pm$ $0.25 \mathrm{~L}$ for the $6^{\text {th }}$ and $2^{\text {nd }}$ lactation respectively. However, although the milk production during the dry-season was relatively low $(0.56 \pm 0.23 \mathrm{~L})$ compared to the rainy season $(0.6 \pm 0.28 \mathrm{~L})$, both were statistically similar $(P$ $=0.171)$.

\section{Mortality rate}

Mortality rates were not different (Chi-square: $0.2, \mathrm{ddl}: 2$ ) in the three phenotypes in the study area: $10.98 \pm 3.41 \%$ for crossbreed; $11.85 \pm 4.19 \%$ for Dwarf taurine and $12.17 \pm 5.06 \%$ for Zebus, with an average of $11.66 \pm 4.23 \%$. Nevertheless, a significant effect $(P=0.003)$ of the calving season was noted. The mortality rates were $17.9 \%$ in the rainy period (August to October), $11.1 \%$ in the dry period (November to March) and 7.3\% during the vegetative re-growth (April to May). 
Table 1: Number of animal sampled per phenotype and location (Administrative Prefecture)

\begin{tabular}{|l|c|l|l|l|}
\hline \multirow{2}{*}{ Study Parameter } & Phenotype /gender & \multicolumn{3}{|c|}{ Animal number per location (Prefecture) } \\
\cline { 3 - 5 } & & Mô & Tchaoudjo & Totals \\
\hline \multirow{4}{*}{$\begin{array}{l}\text { Weight } \\
\text { performance of } \\
\text { calves }\end{array}$} & $\begin{array}{l}\text { Crossbreed } \\
\text { (Dwarf taurine } \times \text { Zebu) }\end{array}$ & $31(15 \%)$ & $37(17.9 \%)$ & $68(32.9 \%)$ \\
\cline { 2 - 5 } & Taurine & $41(19.8 \%)$ & $31(15 \%)$ & $72(34.8 \%)$ \\
\cline { 2 - 5 } & Zebus & $13(6.3 \%)$ & $54(26.1 \%)^{*}$ & $67(32.4 \%)$ \\
\cline { 2 - 5 } & Calving & $46(22.2 \%)$ & $64(30.9 \%)$ & $110(53.1 \%)$ \\
\cline { 2 - 5 } & Calf & $39(18.8 \%)$ & $58(28 \%)$ & $97(46.9 \%)$ \\
\hline \multirow{2}{*}{$\begin{array}{l}\text { Milk } \\
\text { performance }\end{array}$} & Dwarf taurine x Zebus & $72(24.8 \%)$ & $84(29.0 \%)$ & $156(53.8 \%)$ \\
\cline { 2 - 5 } & Dwarf taurine & $66(22.8 \%)$ & $68(23.4 \%)$ & $134(46.2 \%)$ \\
\hline
\end{tabular}

(): percentage of the total; *: number comprising two female dipoles

Table 2: Average birth weights and Chest Girths of calves by phenotype and gender

\begin{tabular}{|c|c|c|c|c|}
\hline Variables & Phenotype & Gender & Average & $P$-value \\
\hline \multirow{7}{*}{$\begin{array}{l}\text { Birth weight } \\
\text { (kg) }\end{array}$} & \multirow{2}{*}{$\begin{array}{l}\text { Crossbred cattle (Dwarf } \\
\text { taurine } \times \text { Zebu) }\end{array}$} & Female & $16.59 \pm 0.35$ & \multirow[t]{2}{*}{0.063} \\
\hline & & Male & $17.71 \pm 0.39$ & \\
\hline & \multirow[t]{2}{*}{ Dwarf taurine } & Female & $12.33 \pm 0.35$ & \multirow[t]{2}{*}{$0.000^{*}$} \\
\hline & & Male & $13.73 \pm 0.36$ & \\
\hline & \multirow[t]{3}{*}{ Zebu } & Female & $19.67 \pm 0.38$ & \multirow[t]{3}{*}{$0.000^{*}$} \\
\hline & & Male & $22.55 \pm 0.39$ & \\
\hline & & Twin female & $14.50 \pm 1.07$ & \\
\hline \multirow{7}{*}{$\begin{array}{l}\text { Chest Girth } \\
\text { (cm) }\end{array}$} & \multirow{2}{*}{$\begin{array}{l}\text { Crossbred cattle (Dwarf } \\
\text { taurine } \times \text { Zebu) }\end{array}$} & Female & $58.70 \pm 0.38$ & \multirow[t]{2}{*}{0.3} \\
\hline & & Male & $59.16 \pm 0.41$ & \\
\hline & \multirow[t]{2}{*}{ Dwarf taurine } & Female & $55.93 \pm 0.38$ & \multirow[t]{2}{*}{0.991} \\
\hline & & Male & $55.91 \pm 0.39$ & \\
\hline & \multirow[t]{3}{*}{ Zebu } & Female & $60.19 \pm 0.40$ & \multirow[t]{3}{*}{$0.003^{*}$} \\
\hline & & Male & $62.52 \pm 0.41$ & \\
\hline & & Twin Female & $57.00 \pm 1.14$ & \\
\hline
\end{tabular}

Table 3: Analysis of the effect of genetic and environmental factors on the calf birth weight and the Chest Girth

\begin{tabular}{|l|l|l|l|l|l|l|}
\hline Factors & Variables & SCE & ddl & ECM & D & P \\
\hline Genetic factors & BW & 1085.19 & 2 & 542.59 & 138.17 & $0.000^{*}$ \\
\hline \multirow{2}{*}{ Phenotype } & CG & 457.05 & 2 & 228.53 & 61.94 & $0.000^{*}$ \\
\hline \multirow{2}{*}{ Gender } & BW & 164.68 & 2 & 82.34 & 20.97 & $0.000^{*}$ \\
\cline { 2 - 8 } & CG & 50.361 & 2 & 25.18 & 6.825 & $0.002^{*}$ \\
\hline Environmental factors & BW & 19.24 & 1 & 19.24 & 4.99 & $0.029^{*}$ \\
\hline \multirow{2}{*}{ Season } & CG & 1.92 & 1 & 1.92 & 0.52 & 0.472 \\
\hline Location & BW & 1.05 & 1 & 1.05 & 0.27 & 0.606 \\
\hline & CG & 4.68 & 1 & 4.68 & 1.27 & 0.26 \\
\hline \multirow{2}{*}{ Calving number } & BW & 15.60 & 4 & 3.90 & 0.99 & 0.41 \\
\hline & CG & 7.65 & 4 & 1.91 & 0.52 & 0.72 \\
\hline Genetic $\times$ Environmental factors interactions \\
\hline Season $\times$ location & BW & 0.33 & 1 & 0.33 & 0.08 & 0.77 \\
\hline & CG & 6.12 & 1 & 6.13 & 1.66 & 0.20 \\
\hline Season $\times$ phenotype & BW & 6.02 & 2 & 3.01 & 0.76 & 0.47 \\
\hline & CG & 5.61 & 2 & 2.8 & 0.76 & 0.47 \\
\hline
\end{tabular}

BW: birth weight $(\mathrm{kg})$; CG: Chest Girth $(\mathrm{cm})$; SCE: Sum of squares of gaps; ddl: degree of freedom; ECM: Mean of squares of deviations; D: Anderberg similarity coefficient; $p^{*}$ : statistically significant Fisher values. 


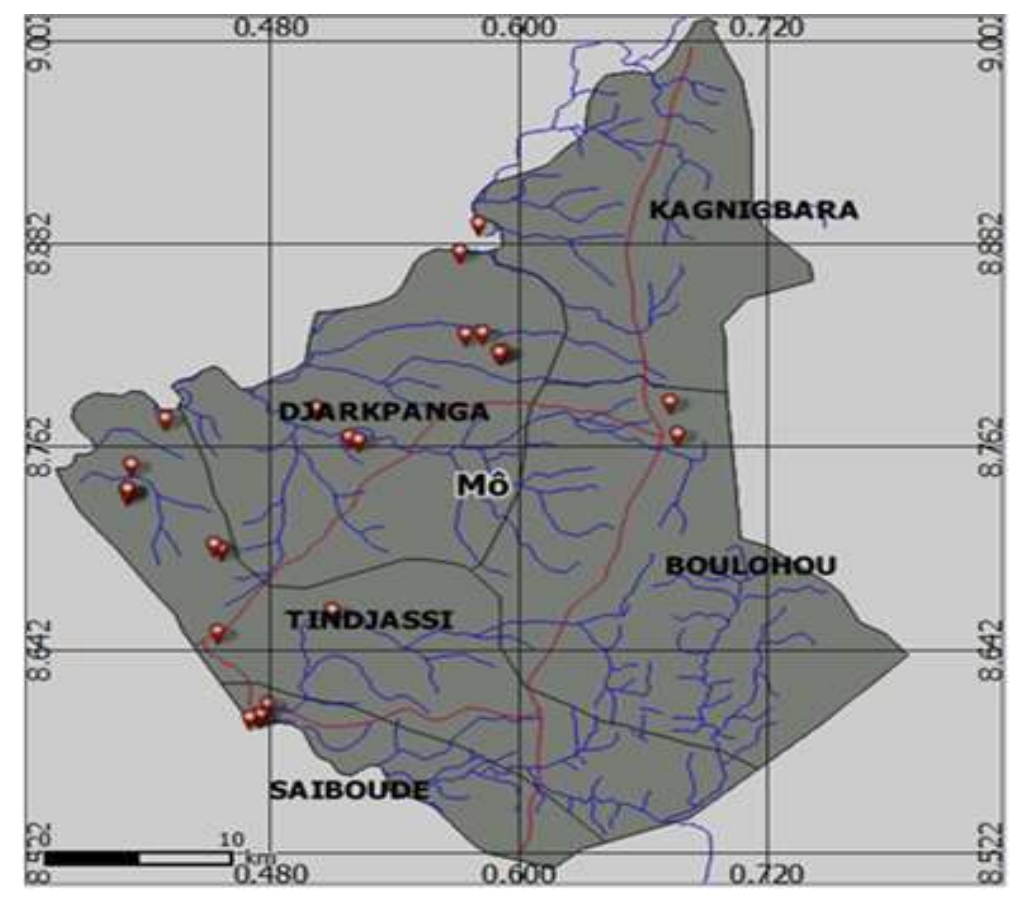

\section{Locality of Mô}

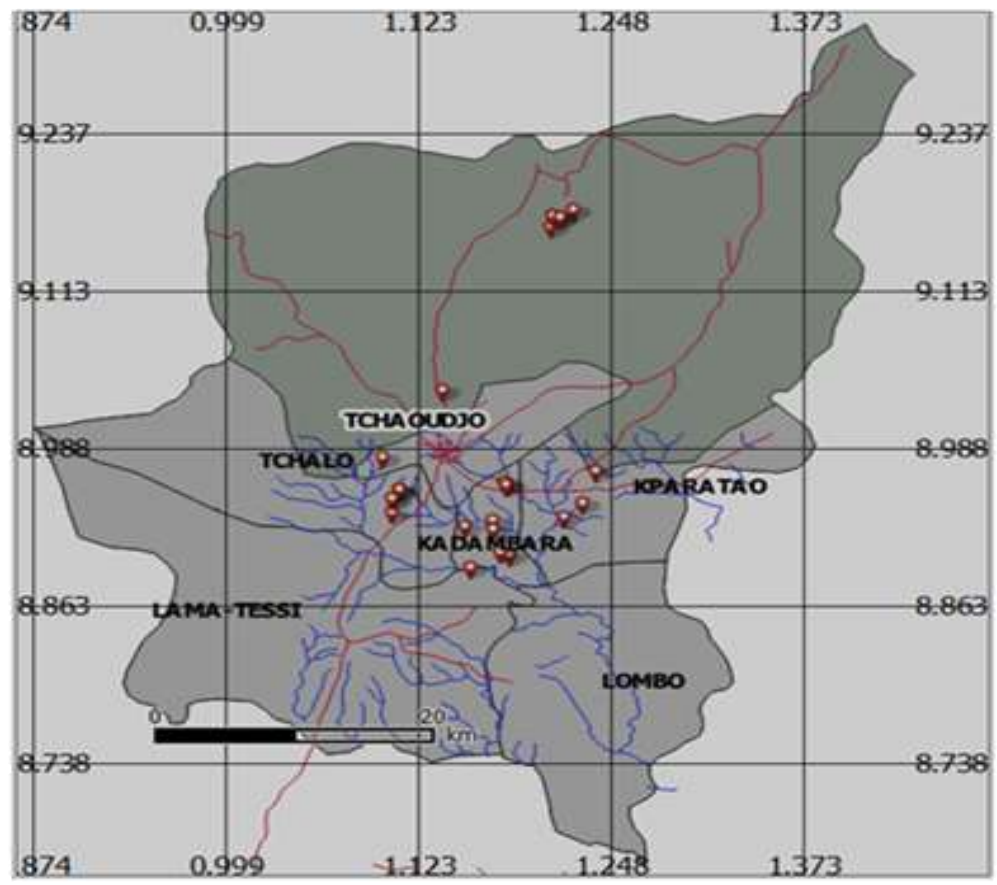

\section{Locality of Tchaoudjo}

- Geographical coordinates of the herds

\section{Road}

Rivers

Fig 1: Maps of the study cattle localities and herds 


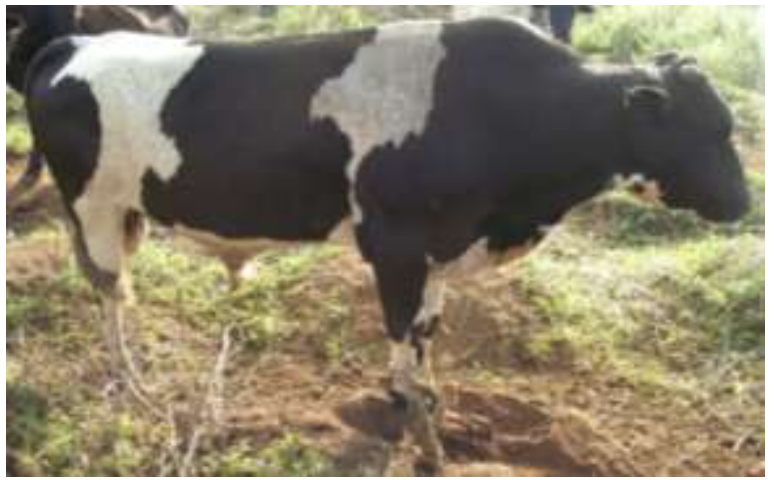

Crossbred (Dwarf taurine $\times$ Zebu) bull

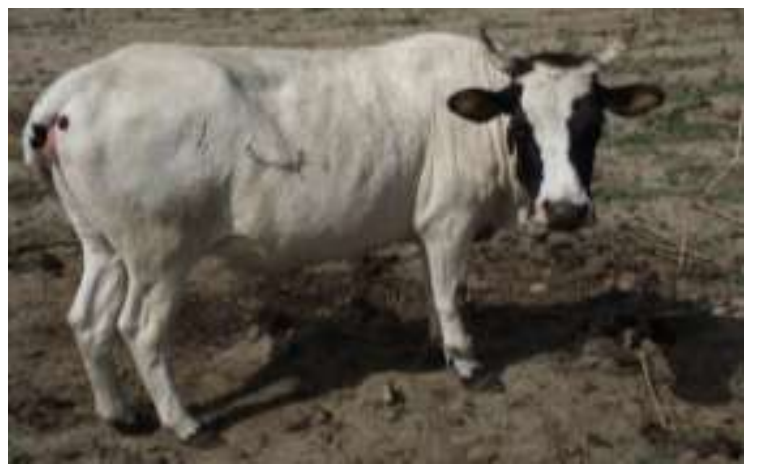

Crossbred (Dwarf taurine $\times$ Zebu) cow

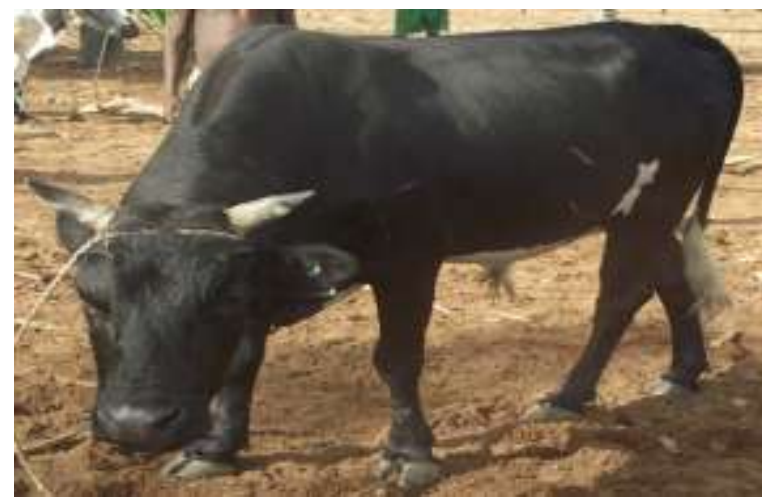

Dwarf taurine (Somba) bull

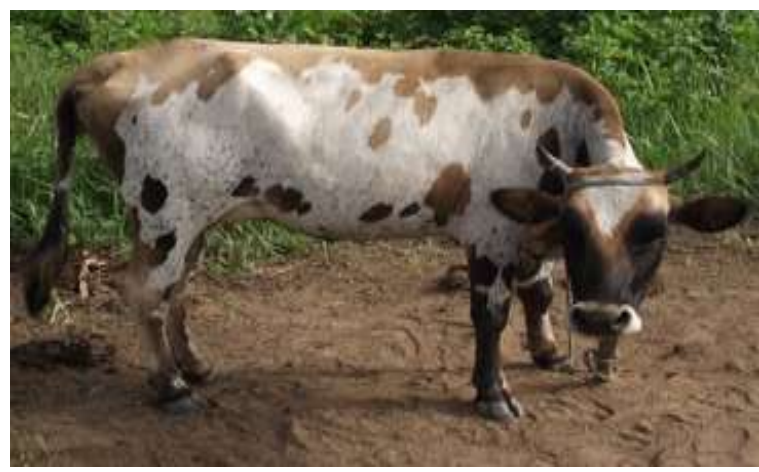

Dwarf taurine (Somba pure breed) cow

Fig 2: The two-phenotypic taurine cattle (Dwarf taurine $\times$ Zebu and Somba pure breed) studied

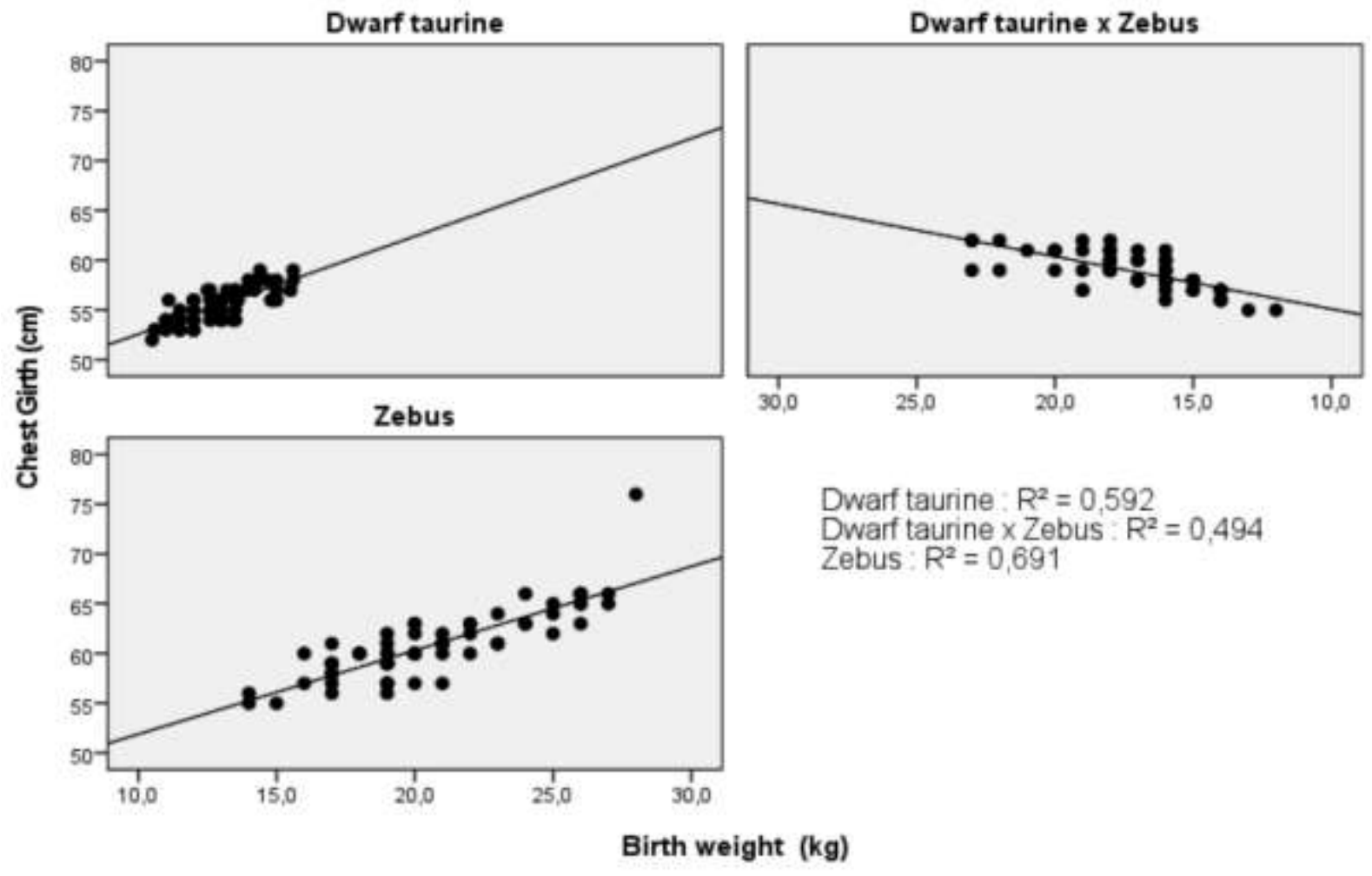

Fig 3: Correlation between birth weight $(\mathrm{kg})$ and Chest Girth $(\mathrm{cm})$ of the phenotypic calves 


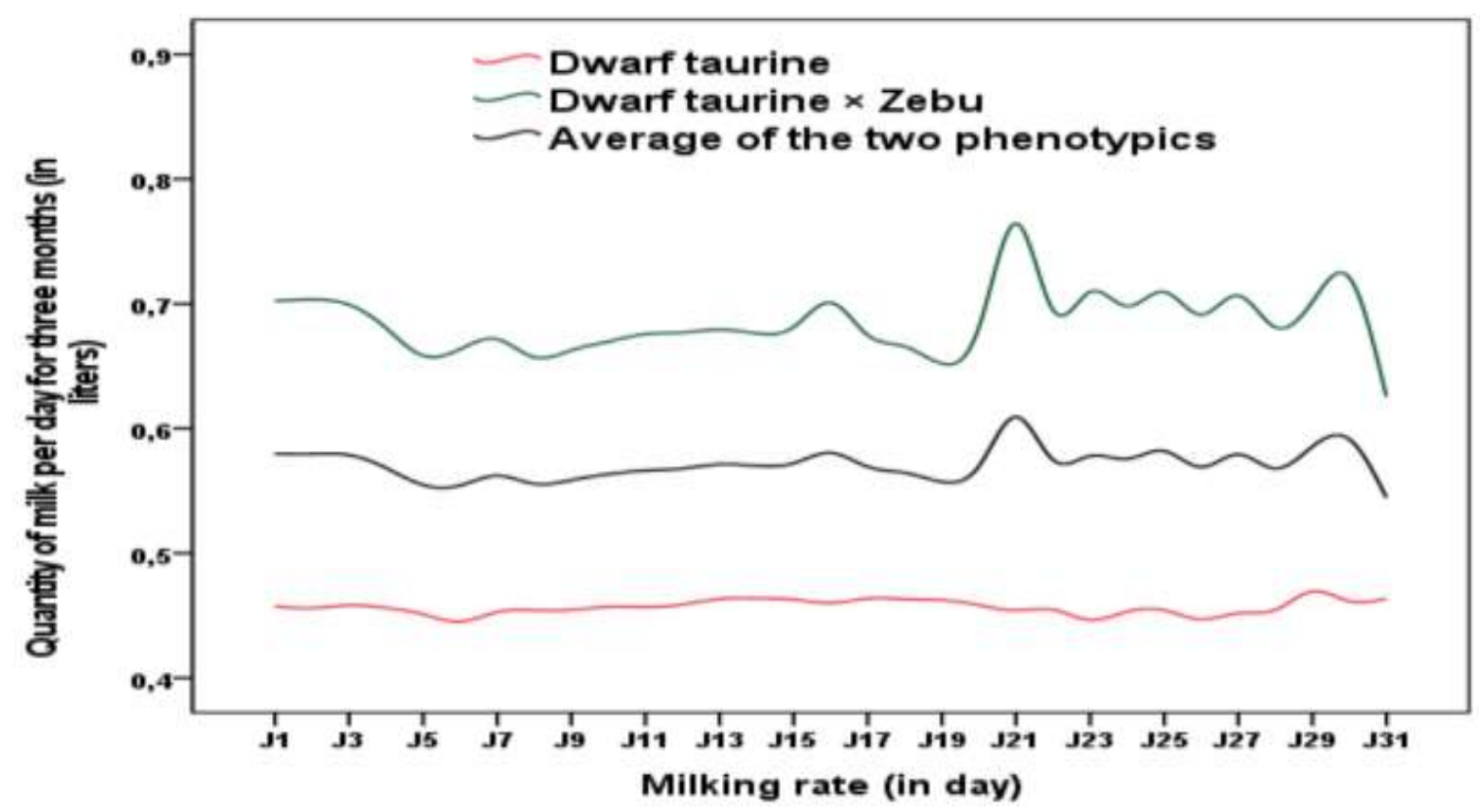

Fig 4: Average daily production of Dwarf taurine and humpless crossbred cattle (Dwarf taurine $\times$ Zebu)

\section{Discussion}

The current survey revealed that the birth weight and the milk production from the local crossbreed (Dwarf taurine $\times$ Zebu) are better than those recorded in the Somba pure breed, but the crossbred cattle daily performance is low compared to Zebu cattle. This is an indication that crossbreeding can indeed improve productive traits of the WAD cattles populations.

Calf birth weight is considered as a crucial factor that leads to survival and for improving growth performances. It is the first trait that provides data on the future development of an animal (Wiener and Rouvier, 2009). The average birth weights of phenotypically taurine breed reported in this study were similar to the findings reported by Alkoiret et al. (2016) of $18.7 \pm 1.8 \mathrm{Kg}$ in the Borgou breed in Benin. Yet, the birth weight of humpless crossbred cattle reported in this survey was higher than the average value $(12 \pm 3 \mathrm{Kg})$ recorded on Somba cattle in their breeding zone in the northeast of Togo (Adanléhoussi, 2003). The CG measured on calves can be used to identify those which have the highest genetic potential for production (Frizzas et al., 2008). A positive and significant correlation between BW and CG was observed in the current survey, suggesting the possibility to improve the BW by selecting animals on $\mathrm{CG}$.

In our survey, male calves had higher birth weight than females. Birth weight was affected by calf gender (Hess et al., 2016). These findings were similar to other survey conducted by Alkoiret et al. (2016) in Borgou cattle population in Benin and in Sanga cattle population in Ghana (Obese et al., 2008). Both surveys showed higher birth weights of male calves. In addition, our survey showed a better survival fitness of crossbred calves, with a better birth weight compared to the Somba pure breed. In the crossbreeding between West-African taurine and Zebu, it is expected crossbred cattle with high production traits from Zebu bull and the high adaptive traits (trypanotolerance, resistance to tick infestation and tick-borne diseases, other adaptive response to environmental fluctuations, from the taurine cattle.

In the current study, BW was affected by the calving season. This effect can be explained by the microclimatic (temperature fluctuations over the year and the season) and nutritional conditions. This may influence the accessibility and availability of quality grazing feeds in both dry and rainy seasons in the survey area. Similar effects were previously reported (Lecomte et al. 1996). In the study, contrary to the birth BW, the $\mathrm{CG}$ was not influenced by the season. Therefore, $\mathrm{CG}$ is more suitable than $\mathrm{BW}$ for the selection or the monitoring of the calf's growth performance purposes.

Our results show that crossbred cattle performed better, $0.68 \pm 0.27 \mathrm{~L}$ of milk / day than the Dwarf taurine breed $(0.46 \pm 0.15 \mathrm{~L}$ per day). This supports the findings reported by Kassa et al. (2016) indicating that Somba taurine breed is a poor dairy cow with really low average daily milk yield of $0.48 \mathrm{~L}$. The performance recorded in the crossbred cows falls within the range $(0,48 \mathrm{~L})$ of performances reported in the Borgou breed in extensive breeding system and in Somba breeding area in Benin (Kassa et al., 2016). In Burkina Faso, Zakpa and Kamuanga (2002) recorded a production of $0.7 \mathrm{~L}$ of milk per day in the traditional humpless short-horned cattle breeding system. Even so, it is important to note that the quantity of milk daily recorded in our survey 
corresponds to the quantities of milk for only one time of the day (in the morning) without taking into account the quantity taken by the calves to stimulate the flow of milk.

The average mortality rates recorded in our survey were similar for the three cattle populations. In Benin, Chabi Toko et al. (2016) recorded almost a similar mortality rate of $10 \%$ in Banikoara, Malanville and Kalalé. Our results show a mortality rate of the crossbred cattle slightly lower than those obtained in Somba taurine and zebu breeds. This is in accord with the findings reported by Santoze and Gicheha, (2019) and can be explained by better adaptation to the local environment, which is highly infested by animal trypanosomiasis (Talaki et al., 2014).

The search for improving local cattle production is the goal of traditional crossbreeding, and will continue to be the main approach driving the resilience in the traditional cattle production forward (Berghof et al., 2019). Yet, the challenge of crossbreeding as a breeding strategy is the risk of introgression of pure Somba and Laguna populations well adapted to their environment (Koudandé et al., 2009). The phenotypes resulting of crossbreeding, generally, cannot be distinguished with the parental Somba and Laguna breed. However, increased community awareness and improved refuge areas will contribute to safeguarding the holding areas where controlled movement can subsequently be organized together with small holder farmers.

\section{Conclusion}

A significant difference between Somba taurine breed, crossbred cattle (Dwarf taurine $\times$ Zebu) and Zebu phenotypes was observed for birth weight and milk yield traits in the current study. Optimized crossbreeding programs for productive traits would generate more income for livestock breeders. Dwarf taurine breed performed poorly compared to humpless crossbred cattle and Zebus phenotypes in terms for birth weight and milk yield. Our results suggest that crossbreeding could be an approach to improve the traditional production system. However, the prerequisite is to have more information on the genetics status of the cattle population through a good characterization of the different populations using phenotypic and molecular tools.

\section{Acknowledgements}

The data were collected partly during the animal trypanosomosis control activities of the Mô Rural Development Project in Togo (PDRI-Mô). The authors thank and acknowledge the initiators of this project, which agreed to make its extension staff available for our data collection. The authors highly acknowledge PPAAO-Togo (IDA $\mathrm{N}^{\circ} 5955-\mathrm{TG}$ ), for funding the study.

\section{Funding}

The survey was funded by PPAAO-Togo (IDA N5955-TG).

\section{Authors' contributions}

Dr Dayo Guiguigbaza-Kossigan and Dr Yao Lombo, have been involved in the data collection protocol, analysis and interpretation of the result, revising content of the article. They approved the final version to be published. Dr Djagba Atouga Yembliman, Dr Seme. Kpassi, Mr Assota Kossaoga, Mr N'Féidé Toï and Dr Mollong Eyabana, have been involved in the field data collection, analysis of the result and revising content of the article. They approved the final version to be published. Dr Nuto Yaovi and Dr Omasaki Simon Kipkemboi have been involved in the analysis and interpretation of the result, revising the scientific content and language style of the article. They approved the final version to be published.

\section{Conflict of Interest}

The corresponding author has received $\mathrm{PhD}$ research grants from PPAAO-Togo (IDA $\mathrm{N}^{\circ} 5955-\mathrm{TG}$ ). The authors declare that they have no conflict of interest.

\section{References}

1) Adanléhoussi A, Bassowa H, Défly A, Djabakou K, Adoméfa K, Kouagou NT, 2003. Les performances de la race taurine Somba en milieu paysan. Tropicultura, 21, 135-141.

2) Alkoiret IT, Gbangboche BA, Toukourou Y, Toure ZF 2016. Performances de croissance des bovins Borgou et N'Dama à la ferme d'élevage de l'Okpara au nord Bénin. Journal of Animal and Plant Sciences 29, 4638-4650.

3) Belemsaga DMA, Lombo Y, Thevenon S, Sylla S 2005. Inventory Analysis of West African Cattle Breeds. In Applications of Gene-Based Technologies for Improving Animal Production and Health in Developing Countries. https://doi.org/10.1007/1-4020-3312-5_15

4) Berghof TVL, Poppe M, Mulder HA, 2019. Opportunities to Improve Resilience in Animal Breeding Programs. Frontiers. Genetics 9, 692.

5) Boma S, Nuto Y, Dayo G-K, Bonfoh B, N'Féidé T, 2018. Caractérisation morpho-biométrique des populations bovines locales sans bosse du Togo. International Journal of Biological and Chemical Sciences 12, 431-445.

6) Chabi Toko R, Adégbidi A, Lebailly P, 2016. Demography and zootechnical performance of traditional cattle farming in Northern Benin. Revue d'élevage et de médecine vétérinaire des pays tropicaux 69, 33-39. 
7) Courtin F, Sidibé I, Rouamba J, Jammoneau V, Gouro A, 2009. Impacts observés des évolutions démographiques et climatiques sur la répartition spatiale des hommes, des tsé-tsé et des trypanosomoses en Afrique de l'Ouest. Parasite 16, 3-10.

8) Dossa HL, Vanvanhossou SUF, 2015. The indigenous Somba cattle of the hilly Atacora region in North-West Benin: threats and opportunities for its sustainable use. Tropical Animal Health Production 48, 349-359.

9) Frizzas OG, Grossi DA, Buzanskas ME, Paz CCP, Bezerra LAF, Lôbo RB, Oliveira JA, Munari DP, 2009. Heritability estimates and genetic correlations for body weight and scrotal circumference adjusted to 12 and 18 months of age for male Nellore cattle. Animal, 3, 347-351.

10) Hanotte O, Ronin Y, Agaba M, Nilsson P, Gelhaus A, Horstmann R 2003. Mapping of quantitative trait loci controlling trypanotolerance in a cross of tolerant West African N'Dama and susceptible East African Boran cattle. Proceedings of the National Academy of Sciences of the United States of America 100, 7443-8.

11) Hess MK, Hess AS, Garrick DJ, 2016. The effect of calf gender on milk production in seasonal calving cows and its impact on genetic evaluations. PLoS ONE 11 (3).

12) Kassa SK, Ahounou S, Dayo G-K, 2016. Performances de production laitière des races bovines de l'Afrique de 1'Ouest. International Journal of Biological and Chemical Sciences 10, 2316-2330.

13) Koudandé OD, Dossou-Gbété G, Mujibi F, Kibogo H, Mburu D, Mensah GA, Hanotte O, Van Arendonk JAM, 2009. Genetic diversity and Zebu genes introgression in cattle population along the coastal region of the Bight of Benin. Agriculture, 44, 45-55.

14) Lecomte $\mathrm{Ph}$, Buldgen $\mathrm{A}$, Hellemans $\mathrm{Ph}$, Compère $\mathrm{R}$, 1996. Caractérisation des variations saisonnières de la qualité des repousses des végétations naturelles de savane en région guinéenne (Ranch de l'Adélé, Togo). Annales Zootechnie, Elsevier / INRA.

15) Obese FY, Darfour-Oduro KA, Bekoe E, Hagan BA, Gomda Y, 2008. Reproductive status following artificial insemination in Sanga cows in the Accra Plains of Ghana. Livestock Research for Rural Development 20 (12).

16) Okeyo MO, Hanotte O, Kwon Y-J Cho S, 2015. African Indigenous Cattle: Unique Genetic Resources in rapidly changing world. Asian-Australasian Journal of Animal Sciences 28, 911-921.

17) Santoze A, Gicheha M, 2019. The status of cattle genetic resources in west africa : a review. Advances in Animal and Veterinary Sciences 7, 112-121.

18) Talaki E, Dao B, Dayo G-K, Alfa E, N'Féidé T, 2014. Trypanosomoses animales dans la Plaine de Mô au Togo. Int. J. Biol. Chem. Sci., 8 (6) : 2462-2469.

19) Tano K, Faminow M, Kamuanga M, Swallow B, 2003. Using conjoint analysis to estimate farmer's preferences for cattle traits in West Africa. Ecological Economics 45, 393-407.

20) Wiener G, Rouvier R 2009. L'amélioration génétique animale. Agriculture tropicale en poche. Quae CTA presses agronomique de Gembloux (France).

21) Youssao AKI, Ahissou A, Touré Z, 2000. Introduction de la race bovine N'Dama à la Ferme Elevage de l'Okpara au Bénin. Quelques performances zootechniques. Animal Genetic Resources Information 27, $17-25$.

22) Zakpa L, Kamuanga M, 2002. Synthèse de quelques travaux du PRAD sur la productivité des bovins sous contraintes glossinaires : Compte rendu de la 1ère réunion du dialogue régional, 31 juillet au 2 août 2002 ; Bobo-Dioulasso (Burkina-Faso). 